Originalveröffentlichung in: Penz, François ; Koeck, Richard (Hrsgg.):

Cinematic urban geographies, New York, NY 2017, S. 65-77

CHAPTER 4

\title{
Charting the Criminal: Maps as Devices of Orientation and Control in Fritz Lang's $M(1931)$ and Francesco Rosi's Le mani sulla città (1963)
}

\author{
Henry Keazor
}

The Power Exerted on and by the Map

In his books The Power of Maps (1992) and Rethinking the Power of Maps (2010) the American cartographer and map historian Denis Wood insists that maps are not just representations of the real world. Rather, they are socially constructed arguments based upon consistent semiotic codes, and that these 'arguments' deal with power and control.

Wood's British colleague, John Brian Harley, had already developed a distinction between the external and internal power of cartography in 1989, by defining external power in a twofold way (Harley 1989). On the one hand, according to Harley, maps can be seen as a reflection of the power that is exerted on cartography. Thus, maps reflect the interests of their authors and of those who commission their production. On the other hand, maps can be seen as a reflection of the power that is exerted with cartography. Maps are used to legitimate claims to power in a variety

H. Keazor (凶)

Heidelberg, Germany

(c) The Author(s) 2017

F. Penz, R. Koeck (eds.), Cinematic Urban Geographies,

Screening Spaces, DOI 10.1057/978-1-137-46084-4_4 
of contexts - they are the graphic manifestation of a given jurisdiction's prevailing legislation or of existing conditions of power.

It is in this respect that the internal power of maps begins to emerge. Harley asserts that the internal power of maps is the potential for cartographers to manufacture power: 'Maps are a technology of power, and the key to internal power is cartographic process' (Harley 1992, p. 244). He here apparently thinks that the capacity to create maps allows for the selection of what is included in and also excluded from maps, which in turn enables the message contained in the map to be manipulated by its creator or creators to suit particular interests. In this chapter, I present three examples in which the power, manifested in and exerted by maps or plans, is used for filmic narratives in order to make the ambiguity of these devices evident. On the one hand, they can be seen as Early Modern tools for gaining and exerting power (see for this also Michalsky et al. 2009, passim). On the other hand, it can be shown that certain effects of Modernity have eroded their power, provoking at the same time a certain loss of control and orientation while offering another way and possibility of gaining and exerting power.

\section{INK AND BLOOD}

Even in recent movies, maps still serve as signs of the control assigned to those who own and know them. Take, for example, Nicolas Winding Refn's Drive (2011). The 'Driver', played by Ryan Gosling, is briefly seen handling a map of Los Angeles at the beginning of the film. A few moments later we witness him administrating the power and control the map gives him when he dexterously outsmarts a police patrol that chases him in the labyrinth of the city of Los Angeles.

The film-historic roots of the portrayal of such control made possible by maps can be traced back to the early years of film, namely to Sergei Eisenstein first full-length feature movie, shot in 1924 and released a year later in April. Stachka (Strike) is a mute film about a strike in 1903 held by the workers of a factory in pre-revolutionary Russia, and their subsequent suppression. Most commentary on the film focuses on the famous sequence in which the violent suppression of the strike is cross-cut with footage of cattle being slaughtered: this is one of the many moments of the film in which animals are used as metaphors for the conditions of individuals and certain groups (see, e.g. Bordwell 1993, p. 54). However, I would like to draw attention to the scenes leading up to this scene. 
In these scenes, the leader of the strike, arrested by the police, is confronted by the Chief of the tsarist police with the offer to collaborate with them. As a sign of his mastery and control, the policeman shows him a map of the district in which the friends and comrades of the strike-leader have withdrawn and barricaded themselves and who, according to the police chief, have already lost the battle. But the revolutionary, disgusted by the attempt to bribe him, hits the Chief in the face. When he does so, some bottles of ink are shaken, but only tilt over when the angered police chief hits the table with both fists, thus provoking the bottles to slop their content over the map (Fig. 4.1a): the spilled ink then stands in for the bloodshed in the district represented on the map, 'the streets running with blood' (Bordwell 2004, p. 384).

The policeman rejoices in this outcome, made clear by the fact that he continues to hit the map, making the ink even spill further so that it covers and drenches the district, standing in as a sign of the ensuing carnage (Fig.4.1b).

\section{MAP AND Murder}

Maps and in this case the plans of architecture are also in the hands of the police in Fritz Lang's $M$ from 1931, a film in which maps are used to hunt down a child murderer who terrorizes the city of Berlin (see Kaes 2000; Büttner and Bareither 2010).

Generally Lang's film is permeated by signs and elements of language: when the killer seeks and finds another of his victims, his profile casts an eerie
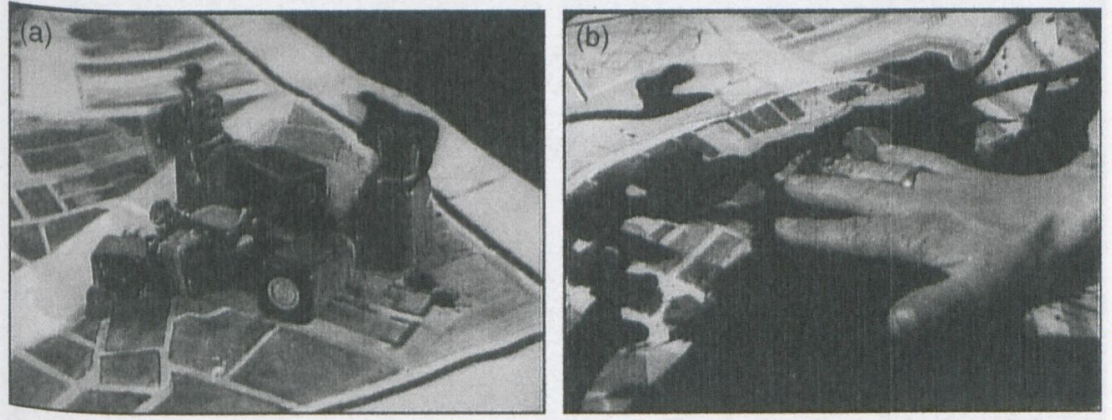

Fig. 4.I (a-b) Sergei Eisenstein, 'Stachka' (Strike), 1924 
shadow on the exact wanted poster related to him. The word 'Mörder' = 'murderer' is here covered precisely by this shadow, thus directly identifying the characteristic silhouette of the hat-wearing man as the sought-after killer in a very visual way (Kaes 2000 , p. 27) (Fig. 4.2).

And when then a child's ball flies up in the air in front of this poster, we immediately understand that its little owner will soon join the other missing, because murdered children, lured into doom also via the appealing shop-windows with their dynamic and at the same time pointing and signalling display decoration. The viewer thus understands that the murderer benefits from these displays since he here approaches the children and begins to win their trust.

But the killer himself also uses signs, letters and languages in order to fool and pressure the police with the help of messages, written by him in

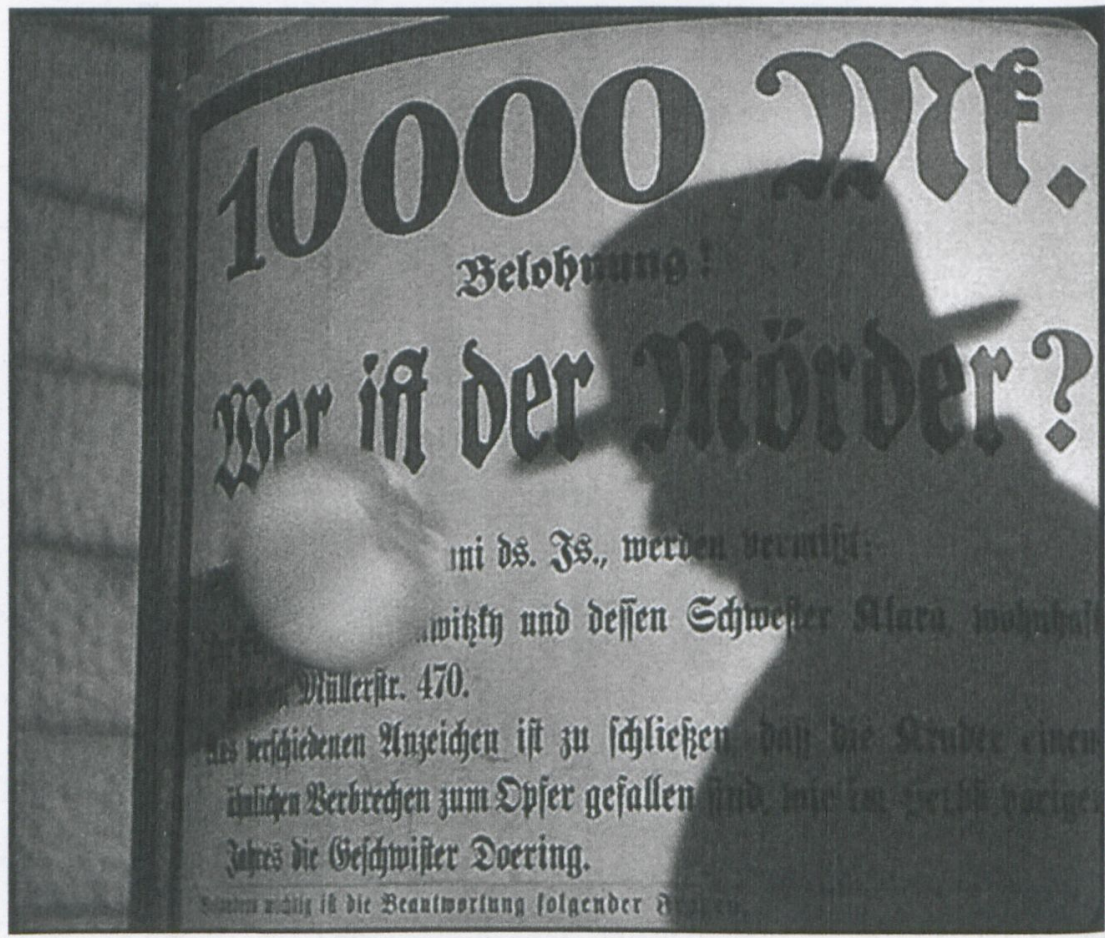

Fig. 4.2 Fritz Lang, 'M', 1931 
an anonymous handwriting. To this, the police responds with the application of tools that make a very abstract and sober use of signs and words: maps (see for this also briefly: Castro 2008). It is indeed striking to observe how much Lang ensures that the settings of his film are permeated by them. Thus, the entire world is represented by globes as well as on maps hanging as posters on the office walls of the police inspectors Groeber and Lohmann. On the next smaller scales Europe and then the city of Berlin are also present on maps hanging on the wall, the map of Berlin being mostly shown behind the investigating police inspector Lohmann (Fig. 4.3a).

There are even more specific types of maps: traffic and transport network maps of the city of Berlin appear when the police recruits beggars and criminals in order to help them to find the killer. Finally, the type of
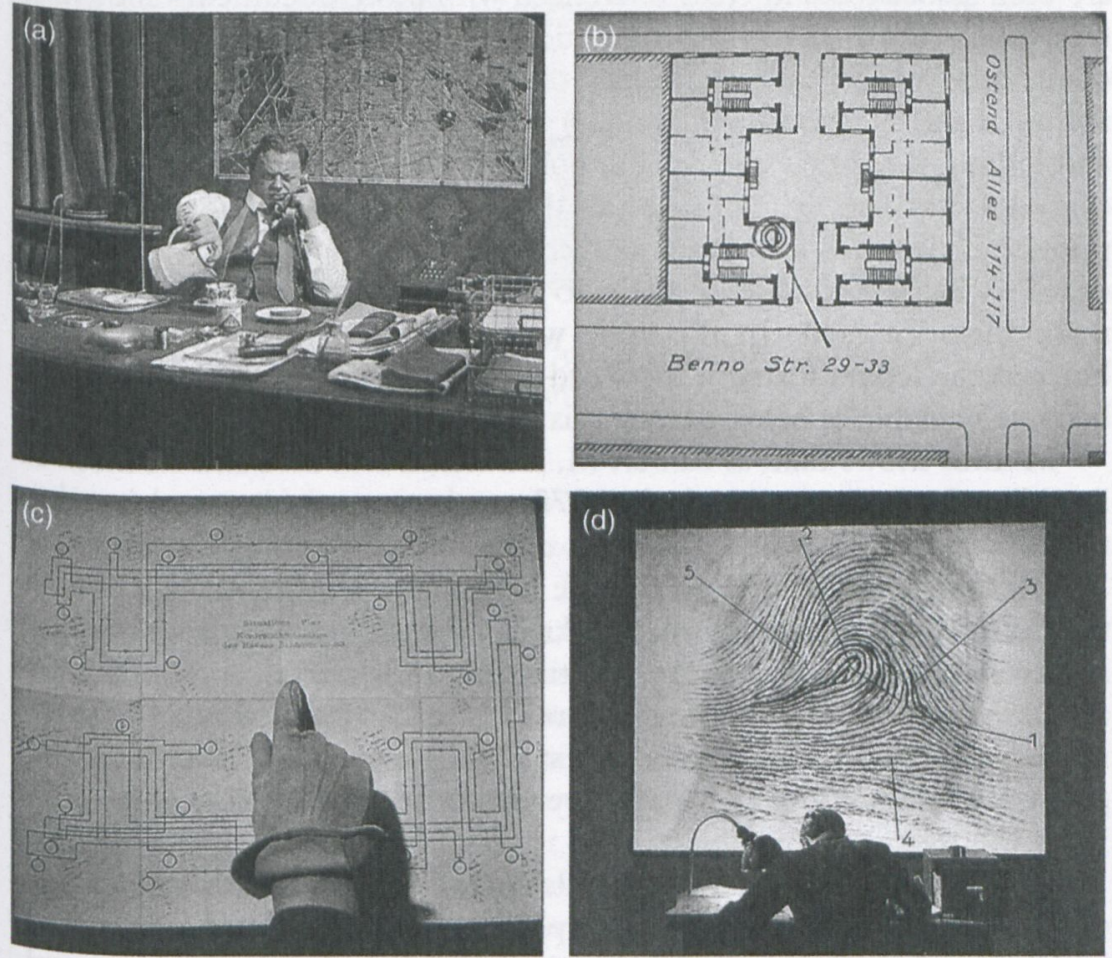

Fig. 4.3 (a-d) Fritz Lang, 'M', 1931 
maps we see are narrowed down to architectural plans of buildings and houses (Fig. 4.3b) and then even further down to the diagram of the electric circuit of an alarm equipment (Fig. 4.3c).

Such different representations, scaling down from the structure of the city to its traffic lines, building plans and finally to diagrams of individual devices, are then later combined when the police actually begins to systematically use the maps instead of just having them hanging on the walls. These maps are then combined and shown in parallel with depictions that go even beyond the focus of circuit diagrams when for example also the finger prints of several suspicious inhabitants of the city of Berlin are analysed and therefore shown in enlarged images on a screen which make them appear like maps of a curved terrain (Fig. 4.3d).

Even though they are thus shown as something very similar to maps, the police investigation nevertheless only makes a decisive step when maps are then associated and cross-referenced with more documents and other reservoirs of knowledge and information. These include address books, file cards, lists (which mirror the lists of the beggars and criminals earlier recruited and assigned by the police) and clinical records. It is combining and linking these that enables the police in the end to encircle the killer (Fig. 4.4a) and to finally mark him the way the maps of circuits, fingerprints and city areas have been marked before with letters and numbers in order to assign and allocate them to a specific information element and make them readable: In the same way, the killer, who had previously blocked the letters forming the word 'Mörder' with his shadow has now become readable as being exactly this 'Murderer'.

' $M$ ' thus shows that, as Robert M. Downs, David Stea and Kenneth E. Boulding have put it already in 1973, maps are not just products, but rather a manifestation of cognitive orientation in space (Downs et al. 1973). One could read Lang's movie as early praise of the possibilities of the information society which, thanks to its ability to associate, combine and cross-reference knowledge, is ultimately able to track and hunt down an elusive criminal. Or one could read it as an expression of 'control mania', an early manifestation of a state dominated by surveillance and police (see Kaes 2000 , p. 46 and already the title of the contribution by Dütsch 2013).

It is interesting in this respect to also glance at Jon J Muth's adaptation of Lang's film into the form of a graphic novel, undertaken by Muth first in 1990 and then, in a revised version, in 2008. In his graphic novel, Muth - due to the change in medium (that is from a sequence of filmed, 

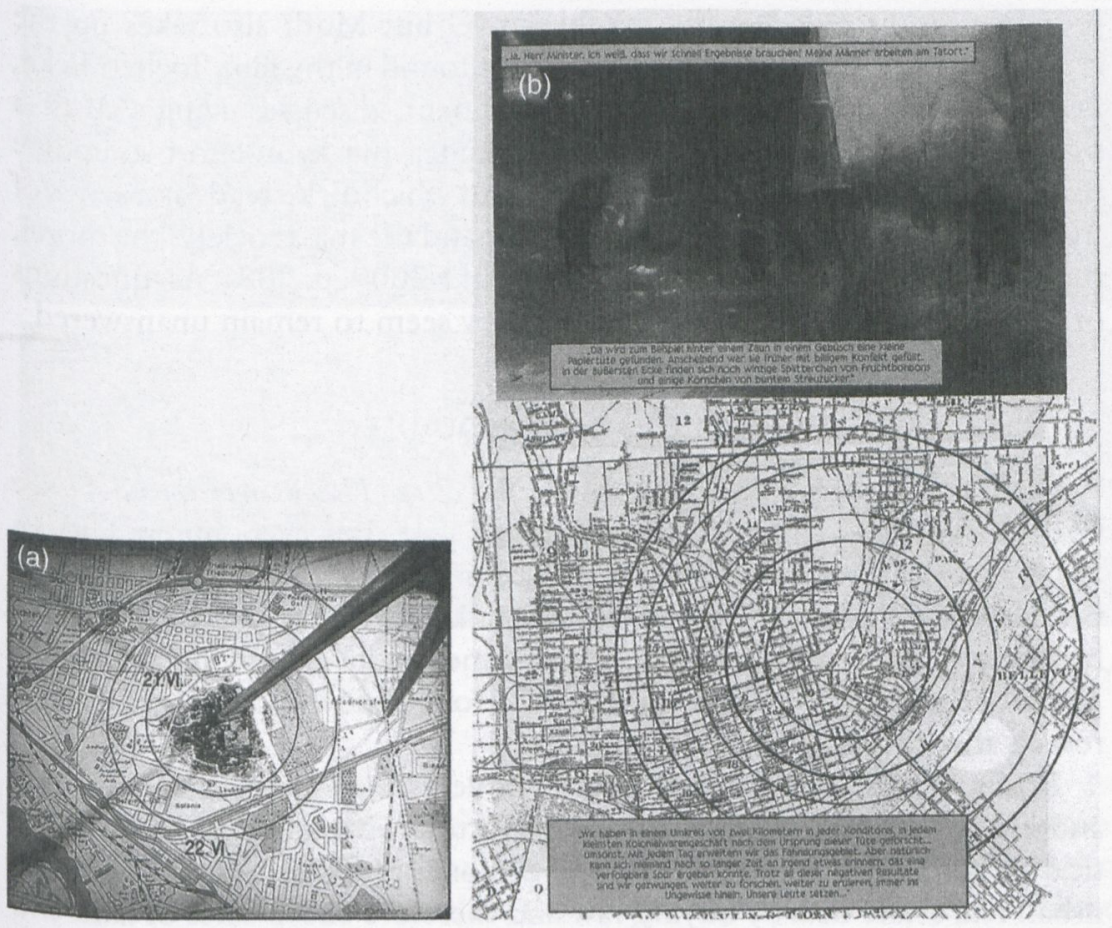

Fig. 4.4 (a-b) Fritz Lang, 'M', 1931/Jon J Muth, 'M', 2008 (art and words by Jon J Muth originally published by Abrams ComicArts)

moving images which run in their own time to a sequence of still-standing pictures which can be viewed and read at the will of the reader) - has not just 'remade', repainted or repeated Lang's film by capturing it scene by scene into drawn images. Rather, he has carefully adapted and translated $M$ into the new medium. In other words, he has not only modernized the context by setting the action in a rather contemporary city or changed the look of the protagonists but also he often finds suiting alternatives to Lang's cinematic way of narrating and editing the story by adding new elements or by sometimes downright by changing and inverting things to the opposite. But despite all these changes, additions and omissions, Muth seems to have understood the motive of the maps as fundamental to the plot to such an extent that he, too, makes recourse to it. Thus, we not only have the maps of the city (Fig. 4.4b) and the plan of electric devices 
prominently displayed in the graphic novel but Muth also takes up the cross-referenced lists and documents motif found in the film. Jochen Ecke, in his 2009 comment on Muth's experiment, discusses Lang's $M$ as a matter, of course, and interprets Muth's endeavour as an effort to update the meaning and the message of Lang's film which Ecke reads as a series of 'big themes of Modernity' ('the individual and the mass society, the moral, the haunting loneliness', as Ecke puts it: Ecke 2009, p. 208). As 'questions of the Modernity', according to Ecke, they seem to remain unanswered.

\section{Maps Versus Liquidity}

With Francesco Rosi's movie Le mani sulla città (Hands over the City - see Gieri 1996; Paparcone 2011) from 1963, we, however, might find an answer to this question, since things seem to have decisively changed in the course of the 32 years between Lang's $M$ and Rosi's film. At first sight, however, it seems as if Rosi follows the same model as seen in Eisenstein's Strike or Lang's $M$ by using the map as a tool of power. But a closer look reveals that this is actually not the case.

Rosi's film is centred around the ruthless Neapolitan land developer and elected city councilman Edoardo Nottola who manages to use political power in order to make a huge personal profit in a large-scale suburban real estate deal by buying raw and therefore cheap acres of land and then selling it as expensive building plots. However, it turns out that the Neapolitan area with its instable geologic conditions, prone to earthquakes, is not the ideal site for such plans. Nottola nevertheless continues. When a residential building in Naples collapses, the Communist councilman Da Vita initiates an inquiry on Nottola's possible connection with the accident, and he seems to be able to prove the responsibility of Nottola however, due to a clever strategy and the corruption of his fellow politicians Nottola ultimately triumphs.

Given that Nottola is a land developer and builder, Rosi uses the opportunity to surround Nottola, like the police chief in Strike or the police inspector in $M$, with a series of maps and models which also function as a sign of Nottola's control (see for this also Pause 2012, p. 178). The title of the movie, The Hands over the City, is variously interpreted in a visual way throughout the film.

For example, at the beginning Nottola talks and explains his plans while expressively waving his hands in the direction of the city, thus metaphorically exerting control over it (Fig. 4.5a). He then draws a square meter into the ground and names its price, thus occupying and selling it 

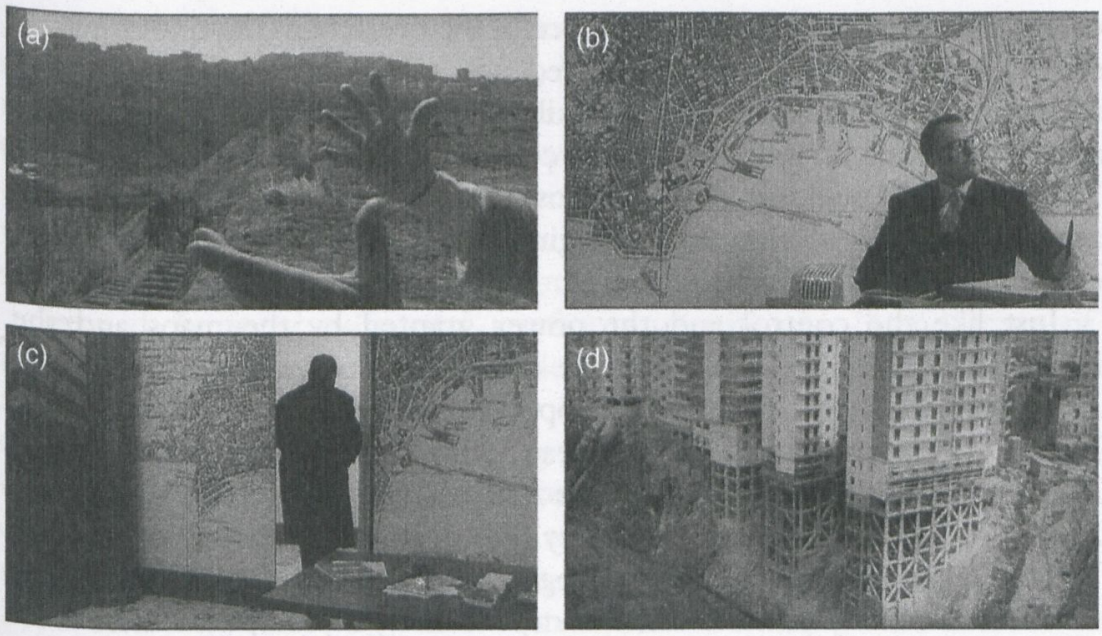

Fig. 4.5 (a-d) Francesco Rosi, 'Le mani sulla città' (Hands over the City), 1963

symbolically. Next, a perspective shot appears in which the housing structures are dwarfed when the politicians are standing around a model of the site and its buildings, before then the office of Nottola is shown, towering high above the city, where not only the model stands (blending into the view of the city, stretching below the window) but also the map of the city is displayed which covers the wall of Nottola's office in such a way that even an escape door opens in it (Fig. $4.5 \mathrm{~b}, \mathrm{c}$ ).

As in $M$, where the police combines maps with other sources of information, Nottola's adversary Da Vita has maps and plans, files and lists at his disposition - but they turn out to be useless when he tries to use the contained information against Nottola: the plans are not exact enough to prove the builder's fault or they are actually treacherous. As one expert explains, Naples is not one but actually two cities situated one above the other. One is aboveground and visible, the other below, invisible and also impossible to map because the conditions underground continuously change due to earthquakes, floods and infiltrations of waters. The expert concludes: 'Our administration ordered all these maps, but they turned out useless.' This, however, means that also Nottola with his plans, maps and models has no insight into and no control over these forces - but given his ruthlessness, he does not care and takes the risks at the costs of 
others. At the same time, the existence of the ever-changing underground structures which cannot be captured and pictured function also as a metaphor for the inscrutable, rapidly shifting and thus disorientating administrational as well as political conditions which ultimately prevent $\mathrm{Da}$ Vita from tracking down, exposing and convicting Nottola (who achieves a quickly shifting and changing of the alliances between fractions and individual politicians).

Just like the control and the power granted by the maps and the information used in Lang's $M$, one can read also Rosi's Le mani sulla città with the help of two philosophical concepts. First, in 1980 the French philosopher Michel de Certeau in his book L'invention du quotidien (the literal translation being The Invention of the Everyday despite the English title The Practice of Everyday Life: see the translation by Rendall 1984) distinguished two different logics of space. One logic functions as the domination of places via the view, meaning a panoptical control of space from a distinct, constant spot. Here, 'alien forces', that is the other and the others, are transformed into objects which can be observed, measured, controlled and then assimilated to their particular point of view, resulting, for example, in maps ('cartes') where the collected data are recorded (de Certeau 1990, pp. 60-61). The other logic of space according to Certeau is a heterogeneous and flexible practice that does without such a safe and measuring distance and instead mingles and moves through the space, experiencing it while making one step after the other and thus lacking during this course ("parcours") the confident control or power of the 'domination of places via the view'.

Applied to Lang's and Rosi's films, one could say that the police in $M$ first act according to the second logic, groping in the dark, before successfully achieving panoptical control via maps, files and plans. In Le mani sulla cittì such a panoptical view is pursued by Da Vita who tries to bring light into the darkness of corruption and chaos, but ultimately the control connected to this panoptical view slips from everybody's grasp due to the unpredictability of the geological as well as political conditions.

This shift - from stable, mappable conditions which allow mastery and control, to dynamic slippery and inscrutable conditions which forbid such control - can be read secondly with concepts of the Polish sociologist Zygmunt Bauman: In his books, in particular Liquid Modernity (2000) and Liquid Life (2005), he has developed a vocabulary that uses the term of 'liquidity' as a metaphor for disorientation, for the dissolution of firm boundaries (Bauman 2000, 2005). Brought into context to Lang's and 
Rosi's films, one could say that $M$ presents, as Bauman calls it, the 'solid stage of modernity' (Bauman 2003, p. 28), an era in which humankind erected new solid certainties in place of earlier ones from pre-modern times, swept away by change and progress. It thus does not perhaps come as a surprise that Bauman here refers to George Orwell's 1984 with its totalitarian and panoptical control state as a perfect example of what this solid stage of modernity could become in the worst case.

Instead Le mani sulla citta confronts us with the 'liquid stage of modernity' where old rules, certainties and identities are not replaced by stable, reliable new ones but where instead an ever switching, dynamic transformation is the order of the day. One could almost take this 'liquidity' verbally when applying the concept to Rosi's film since in it 'floods, constant infiltrations' are held responsible for the confusion which is a metaphor for the impenetrability, reigning in the administration as well as in politics. It is due to this impenetrability that individuals such as Nottola can stand their ground and prevail.

\section{Towards the Cinematic MAP}

At the end of the film, the foundation block for Notola's next project is laid, then the pile drivers, blessed by the church, are rammed into the ground - and one remembers that similar machines caused the collapse of a building at the beginning of the film. The final sequence, showing the buildings as they stand on wooden stilt-like structures (Fig. $4.5 \mathrm{~d}$ ), hints upon the great probability that more houses will follow and be collapsed, and in this light the party, celebrating the laying of the foundation stone, appears - with its dark garments - almost like a funeral ceremony.

Rosi's closing image, with the overlaid message that the individuals and the facts portrayed in the film are fictitious although the social and ambient reality producing them is not, shows that we are invited to read Rosi's film as a map on its own. 'The usual perception of maps is that they are a mirror, a graphic representation of some aspect of the real world (...) The premise is that a map should offer a transparent window on the world', as John Brian Harley defines the nature of maps in his 2001 book The New Nature of Maps (Harley 2001, p. 35).

In 2007, Alexander Böhnke has emphasized the fact that in these respects, there seem to be parallels between maps and films since the screened film likewise not only seems to be 'a mirror, a graphic representation of some aspect of the real world' but these sights are, in the case of the 
projected, shown film, also offered in the form of 'a window (...) on the world' (Böhnke 2007, p. 149). Publishing in the same year as Böhnke, Tom Conley also considers the parallels between maps and films when he describes the guiding hypothesis of his book according to which 'a map in a film is an element at once foreign to the film but also, paradoxically, of the same essence as film' (Conley 2007, p. 2). He nevertheless suggests to also take the differences between maps in film into account and to use the thus opened tension between the two:

A map underlines what a film is and what it does, but it also opens a rift or brings into view a site where a critical and productively interpretative relation with the film can begin. (Conley 2007, p. 2)

Seen in this light, one could take up Harley's notions of the 'mirror' and the 'window' and say that in his film Rosi offers us such a mirror and window. But in the case of Le mani sulla citta it does not come in the form of the traditional, geographical and abstracting map, but instead via a visual representation in moving images resulting in a symbolic depiction which highlights relationships. One could therefore read Rosi's film as a kind of a cinematic map that reflects upon the power that is exerted in and on modern society.

\section{BIBLIOGRAPHY}

Bauman, Z 2000, Liquid Modernity, Polity Press, Cambridge/Malden.

Bauman, Z 2003, 'Education's Challenges in the Liquid Modern Era', in Knowledge Society, Information Society and Adult Education, ed. A Bron and M Schemmann, LIT, Münster, pp. 23-42.

Bauman, Z 2005, Liquid Life, Polity Press, Cambridge/Malden.

Böhnke, A 2007, Paratexte des Films. Über die Grenzen des filmischen Universums, transcript, Bielefeld.

Bordwell, D 1993, The Cinema of Eisenstein, Harvard University Press, Cambridge, MA.

Bordwell, D 2004, 'Monumental Heroics: Form and Style in Eisenstein's Silent Films', in The Silent Cinema Reader, ed. L Grieveson and P Krämer, Routledge, New York, pp. 368-388.

Büttner, C, and Bareither, U (eds.) 2010, 'M - Eine Stadt sucht einen Mörder'. Texte und Kontexte, Königshausen \& Neumann, Würzburg. 
Castro, T 2008, 'Les cartes vues à travers le cinéma', Textimage, Cartes et Plans no. 2 [Summer], pp. 1-17. Available from: http://www.revue-textimage.com/ 03_cartes_plans/castro.pdf. [27 January 2015].

Conley, T 2007, Cartographic Cinema, University of Minnesota Press, Minneapolis/London.

De Certeau, M 1990, L'invention du quotidian, Gallimard, Paris. [quoted here from the 1990 edition].

De Certeau, M 1984, The Practice of Everyday Life, trans. S Rendall, University of California Press, Berkeley.

Downs, RM, and Stea, D (eds.) 1973, Image and Environment: Cognitive Mapping and Spatial Behavior, Aldine, Chicago.

Dütsch, W 2013, Kindermord und Ordnungswahn. Fritz Langs erster Tonfilm ' $M$ ' (television broadcast) 5 February 2013, as part of series 'Hintergrund Kultur', Deutschlandfunk. Manuscript. Available from: http://www.deutschlandfunk. de/kindermord-und-ordnungswahn-fritz-langs-erster-tonfilm-m-pdf.media. 6ecbaac66d82c51e10e0b38ab7a6cb43.pdf. [27 January 2015].

Ecke, J 2009, 'Auf der Suche nach dem Neuen im Alten. Fritz Langs und Jon J Muths 'M' (1931/1990)', in M - Eine Stadt sucht einen Mörder, ed. JJ Muth, Süddeutsche Zeitung, Munich, pp. 203-208.

Gieri, M 1996, 'Hands over the City. Cinema as Political Indictment and Social Commitment', in Poet of Civic Courage: The Films of Francesco Rosi, ed. C Testa, Greenwood Press, Westport, CT, pp. 43-59.

Harley, JB 1989, 'Deconstructing the Map', in Cartographica, Vol. 26, no. 2, pp. 1-20.

Harley, JB 1992, 'Deconstructing the Map', in Writing Worlds: Discourse, Text and Metaphor in the Representation of Landscape, ed. TJ Barnes and JS Duncan, Routledge, London, pp. 231-247.

Harley, JB 2001, The New Nature of Maps. Essays in the History of Cartography, The Johns Hopkins University, Baltimore/London.

Kaes, A 2000, M, BFI, London.

Michalsky, T, F Schmieder, and G Engel (eds.) 2009, Aufsicht-Ansicht-Einsicht. Neue Perspektiven auf die Kartographie an der Schwelle zur Frühen Neuzeit, Trafo, Berlin.

Paparcone, A 2011, 'Francesco Rosi's 'Hands Over the City': A Contemporary Perspective on the Camorra', in Mafia Movies. A Reader, ed. D Renga, University of Toronto Press, Toronto, pp. 226-233.

Pause, J 2012, 'Topologien der Macht. Zum filmischen Raum des Polit-Thrillers', in Film als Raumkunst, ed. H Engelke and RM Fischer, Schüren, Marburg, pp. 177-191.

Wood, D 1992, The Power of Maps, The Guilford Press, New York/London.

Wood, D 2010, Rethinking the Power of Maps, The Guilford Press, New York/ London. 